\title{
EVALUATION AND PATHOBIOLOGICAL SIGNIFICANCE OF ZINC, SELENIUM, AND PLATELET LEVELS IN SICKLE CELL ANEMIA
}

\author{
NNODIM JOHNKENNEDY ${ }^{1 *}$, NJOKU CHUKWUDI JOSEPH ${ }^{2}$, OLY-ALAWUBA NKIRUKA ${ }^{3}$ \\ NWAOKORO JOAKIN CHIDOZIE ${ }^{4}$, AMADI JOY ${ }^{3}$, OKECHUKWU-EZIKE NGOZIKA C ${ }^{5}$
}

${ }^{1}$ Department of Medical Laboratory Science, Faculty of Health Science, Imo State University, Owerri, Imo, Nigeria. ${ }^{2}$ Department of Pharmacology, Faculty of Basic Medical Sciences, Niger Delta University, Bayelsa, Nigeria. ${ }^{3}$ Department of Nutrition and Dietetics, Faculty of Health Science, Imo State University, Owerri, Nigeria. ${ }^{4}$ Department of Public Health, Federal University of Technology, Owerri, Imo, Nigeria. ${ }^{5}$ Department of Food Science, Faculty of Science, Imo State University, Owerri, Imo, Nigeria. Email: johnkennedy23@yahoo.com

Received: 10 January 2020, Revised and Accepted: 20 February 2020

ABSTRACT

Objectives: The serum zinc and platelet statuses of sickle cell patients attending General Hospital, Owerri, Nigeria, were investigated.

Methods: Fifty confirmed sickle cell patients (hemoglobin [Hb]SS) age 10-30 years were selected. Fifty normal subjects (HbAA) age 10-30 years were used as control. The zinc and platelets were determined using standard methods.

Results: The levels of serum zinc, selenium, and platelet were significantly decreased in sickle cell anemia $(\mathrm{p}<0.05)$ when compared with the control.

Conclusion: The result suggests that supplementation of sickle cell patients with food and drug-containing zinc might be helpful, particularly in wound healing, as zinc positively correlates with platelet counts. These low zinc, selenium, and platelets could represent a risk for sickle cell anemia.

Keywords: Zinc, Selenium, Platelet, Sickle cell anemia.

\section{INTRODUCTION}

Sickle cell anemia is a genetic disease that affects majorly African countries [1]. It is characterized by a point mutation in the $\beta$-hemoglobin ( $\mathrm{Hb}$ ) gene, leading to the synthesis of sickle $\mathrm{Hb}(\mathrm{HbS})$, which polymerizes when deoxygenated, distorting, and injuring the red blood cell (RBC). It occurs more often among people from parts of the world where malaria is common [2,3]. Africa is the area of the world most threatened by malaria, particularly Nigeria, because it has the most efficient vectors, the Anopheles gambiae complex [4]. Sickle cell trait or disease offers a protective effect against malaria. In sickle cell anemia, the normal round shape of RBCs becomes like crescent moons $[5,6]$. The role of RBCs is to deliver oxygen to the body. In sickle cell anemia, there is abnormal $\mathrm{Hb}$, called sickle $\mathrm{Hb}$ or $\mathrm{HbS}$. This results to RBCs losing its ability to last long because the sickle Hb destroys them $[7,8]$.

Zinc is a trace element and is majorly abundant trace element next to iron in nature [9]. It is an important component of metalloproteins, which has a role in maintaining antioxidant activity, cellular immunity, and immunological integrity. Sickle cell anemia patients may show hypogonadism, mental lethargy, delayed wound healing growth retardation, cell-mediated immune dysfunctions, and abnormal neurosensory changes, which may be due to inadequate zinc $[10,11]$.

Selenium plays an essential role in the health of the immune system. This antioxidant aids to reduce oxidative stress in the body, which lowers inflammation and improves immunity. Increased levels of selenium could be beneficial for boosting the immune system in patients with some disorders like inflammation [12].

In sickle cell anemia, platelet is affected. Platelet is a tiny blood cell that helps the body form clots to stop bleeding. If one of the blood vessels gets damaged, it sends out signals to the platelets. The platelets then rush to the site of damage. They form a plug (clot) to fix the damage [13]. The main function of platelets includes the maintenance of hemostasis, which depends on three of their properties, the endothelial supporting function of platelets, and the ability to form hemostatic plugs and to release lipoprotein material [14].

In this study, the level of zinc and platelet in sickle cell anemia patients was determined to provide information on their status in Owerri, Imo State, Nigeria.

\section{METHODS}

Thirty HbSS diagnosed by hemoglobin electrophoresis (25 males and 25 females) aged 10-30 years were selected for the study. These patients were attending General Hospital, Owerri. Fifty HbAA normal subjects (25 males and 25 females) were used as control.

Blood sample

In all subjects, $4 \mathrm{ml}$ of venous blood was collected into plain and ethylenediaminetetraacetic acid bottle. The samples were spun in a Wisterfuge centrifuge (model 684) at $1000 \mathrm{~g}$ for $10 \mathrm{~min}$ and the serum collected into bijou bottle. Informed consent of the participants was obtained and was conducted in line with the ethical approval of the hospital.

\section{Biochemical assay}

The serum zinc and selenium were determined by atomic absorption spectrophotometric method [15], while the platelet was determined using standard method.

\section{Statistical analysis}

The results were expressed as mean \pm standard deviation. Statistical significance was calculated using Student's t-test. The level of significance was calculated at $\mathrm{p}<0.05$.

\section{RESULTS}

The results of the levels of zinc, selenium and platelet in HbSS and HbAA are indicated below: 
Table 1: Zinc, selenium, and platelet in HbAA and HbSS

\begin{tabular}{lll}
\hline Parameters & HbAA & HbSS \\
\hline Zinc $(\mu / \mathrm{L})$ & $135.41 \pm 6.6$ & $97.58 \pm 8.4$ \\
Selenium $(\mu / \mathrm{dl})$ & $65.40 \pm 7.5$ & $53.97 \pm 8.6$ \\
Platelet $(\mu \mathrm{L})$ & $310.000 \pm 25$ & $227.000 \pm 35$ \\
\hline
\end{tabular}

*Significantly different from control at $\mathrm{p}<0.05$. The levels of zinc, selenium, and platelet were decreased in $\mathrm{HbAA}$ /when compared with the HbSS at $\mathrm{p}<0.05$. Hb: Hemoglobin

The result from Table 1 shows that the levels of zinc, selenium and platelet were significantly decreased in HbSS when compared with $\mathrm{HbAA}$ at $\mathrm{p}<0.05$.

\section{DISCUSSION}

Sickle cell anemia is an inherited disorder characterized by a high potential for oxidative damage due to a chronic redox imbalance in red cells which leads to continuous production of reactive oxygen species (ROS) and clinical manifestations of mild-to-severe hemolysis [16]. In this study, there are significantly lower plasma levels of zinc and platelets in sickle cell anemia. Since patients with sickle cell anemia are under continuous oxidative stress due to sickle cell lipid peroxidation, a deficiency in zinc may lead to sickle cell manifestations. Some pathological effects of zinc insufficiency include the occurrence of skin lesions, growth retardation, impaired immune function, and compromised would healing as can be observed in sickle cell anemia. The generation of ROS can be grossly amplified in response to a variety of pathophysiological conditions such as deficiency in antioxidant, dehydration, hypoxia, inflammation, and infection. ROS generation in RBCs of sickle cell anemia patients could be linked to $\mathrm{HbS}$ auto-oxidation and potentially aberrant mitochondrial function [17]. The decrease in zinc could be linked to non-absorption from the diet due to excess copper or iron which interferes with absorption. This is in line with the work of Nnodim et al. [18].

In spite of a good diet, sickle cell anemia patients may have an inadequate intake of zinc due to chronic pain, reduced appetite, and hemolysis. The reduction in zinc could be linked to increased demand and consumption as well as increased urinary excretion due to impaired renal concentration and hypoxanthinuria $[18,19]$. This is in line with the work of Lassi et al. [20].

Selenium level was observed to be significantly decreased when compared with the control. Selenium plays a crucial role as a cofactor for the reduction of an antioxidant enzyme such as glutathione peroxidase, an enzyme which aids react with potentially harmful oxidizing agents in substances. Therefore, the reduction of selenium in sickle cell may probably create an oxidative stress, leading to vascular occlusion in sickle cell patients. This, in other words, may seemingly result in sickle cell crisis. Low plasma selenium levels observed in this study may also suggest that a weakened antioxidant potential may be associated with sickle cell disease patients. This is in line with the work of Nnodim et al. [12]

Similarly, the level of platelet was significantly reduced. Abnormal platelet counts are relatively common in sickle cell patients suffering from different types of complications. A production defect could result from vaso-occlusive marrow infarction or sepsis. Second, sickle cell-endothelial interaction results in coagulation factor activation and a state of compensated disseminated intravascular coagulation with platelet consumption. This situation is aggravated in crisis [21].

\section{CONCLUSION}

These low zinc, selenium, and platelets could represent a risk for sickle cell anemia.

\section{REFERENCES}

1. Chaturvedi S, Ghafuri DL, Glassberg J, Kassim AA, Rodeghier M, DeBaun MR. Rapidly progressive acute chest syndrome in individuals with sickle cell anemia: A distinct acute chest syndrome phenotype. Am J Hematol 2016;91:1185-90.

2. Nnodim JK, Meludu SC, Dioka CE, Onah C, Chilaka UJ, Obi PC. Altered membrane potential and electrolyte in sickle cell anemia. J Krishna Inst Med Sci Univ 2014;3:70-3.

3. Nnodim JK, Meludu SC, Dioka CE, Martin OI, Ukaibe N, Ihim A Cytokine expression in homozygous sickle cell anaemia. J Krishna Inst Med Sci Univ 2015:4:34-7.

4. Nnodim JK, Meludu SC, Dioka CE, Ihim A, Onyemailoh OB, Obi PC. Antioxidant vitamins and glycated haemoglobin status in sickle cell anaemia. Al Ameen J Med Sci 2014;7:175-7.

5. Elshazly SA, Heiba NM, Abdelmageed WM. Plasma PTX3 levels in sickle cell disease patients, during vaso occlusion and acute chest syndrome (data from Saudi population). Hematology 2014;19:52-9.

6. Gardner K, Thein SL. Super-elevated LDH and thrombocytopenia are markers of a severe subtype of vaso-occlusive crisis in sickle cell disease. Am J Hematol 2015;90:E206-7.

7. Whelihan MF, Lim MY, Mooberry MJ, Piegore MG, Ilich A, Wogu A, et al. Thrombin generation and cell-dependent hypercoagulability in sickle cell disease. J Thromb Haemost 2016;14:1941-52.

8. Alsultan A, Alabdulaali MK, Griffin PJ, Alsuliman AM, Ghabbour HA Sebastiani P, et al. Sickle cell disease in Saudi Arabia: The phenotype in adults with the Arab-Indian haplotype is not benign. Br J Haematol 2014; 164:597-604.

9. Hess SY, Peerson JM, King JC, Brown KH. Use of serum zinc concentration as an indicator of population zinc status. Food Nutr Bull 2007;28:S403-29.

10. Prasad AS. Discovery of human zinc deficiency: 50 years later. J Trace Elem Med Biol 2012;26:66-9.

11. Stewart-Knox BJ, Simpson EE, Parr H, Rae G, Polito A, Intorre F, et al. Zinc status and taste acuity in older Europeans: The ZENITH study. Eur J Clin Nutr 2005;59 Suppl 2:S31-6.

12. Nnodim JK, Meludu SC, Dioka CE, Onah C, Ihim A, Atuegbu C. Trace elements deficiency in patients with homozygous sickle cell disease. $\mathrm{Br}$ J Med Med Res 2014:4:3879-88.

13. Buseri FI, Jeremiah ZA, Shokunbi WA. Plasma levels of some blood coagulation parameters in Nigerian homozygous sickle cell patients (HbSS) in steady state. Hematology 2006;11:375-9.

14. Anea CB, Lyon M, Lee IA, Gonzales JN, Adeyemi A, Falls G, et al. Pulmonary platelet thrombi and vascular pathology in acute chest syndrome in patients with sickle cell disease. Am J Hematol 2016;91:173-8.

15. Ochei J, Kolhatkar A. Medical Laboratory Science Theory and Practical. $7^{\text {th }}$ ed. McGraw-Hill; Noida; 2008. p. 177-87.

16. Kuypers FA. Hemoglobin s polymerization and red cell membrane changes. Hematol Oncol Clin North Am 2014;28:155-79.

17. Foster M, Samman S. Zinc and regulation of inflammatory cytokines: Implications for cardiometabolic disease. Nutrients 2012;4:676-94.

18. Nnodim JK, Nwobodo E, Nwadike NN, Edward U, Aloy-Amadi O, Obi P. Evaluation of albumin zinc and Vitamin $\mathrm{C}$ in surgical wound patients. Med Sci Healthc Pract 2017;1:60-6.

19. Lazzerini M, Wanzira H. Oral zinc for treating diarrhoea in children. Cochrane Database Syst Rev 2016;12:CD005436.

20. Lassi ZS, Moin A, Bhutta ZA. Zinc supplementation for the prevention of pneumonia in children aged 2 months to 59 months. Cochrane Database Syst Rev 2016;12:CD005978.

21. Pakbaz Z, Wun T. Role of the hemostatic system on sickle cell disease pathophysiology and potential therapeutics. Hematol Oncol Clin North Am 2014;28:355-74. 